\title{
Human Resource Management Practices, Employee Competence and Employee Performance at National Police Service of Kenya
}

\author{
Christine N. Mugambi ${ }^{1}$, Dr. Florence Muindi, $\mathrm{PhD}^{2}$, Dr. Mercy Munjuri, $\mathrm{PhD}^{3}$, Professor Martin Ogutu, $\mathrm{PhD}^{4}$ \\ School of Business administration, University of Nairobi, PO box P.O Box 30197 NAIROBI, 00100, G.P.O, \\ Kenya
}

\begin{abstract}
The aim of this study was to determine the effect of employee competence on the relationship between HRM Practices and employee performance. The research was based on ability, motivation and opportunity theory and human capital theory. Positivism research philosophy and descriptive cross-sectional survey were used. Stratified random sampling was used to study a sample of 384 National Police Service officers. Primary data was collected using structured questionnaires. Data was analyzed using inferential statistics. The study findings showed that employee competence moderates the relationship between human resource management practices and employee performance at the National Police Service. Similar study should be done using the private security sector in Kenya especially this time when the private security guards are being empowered by issuing them with guns Keywords: Human Resource Management Practices, Performance, National Police Service, Kenya

DOI: $10.7176 / \mathrm{EJBM} / 13-22-04$
\end{abstract}

Publication date: November $30^{\text {th }} 2021$

\section{Introduction}

HRM practices relate to proper policies, which may attract and retain employees (Indermun, 2014). HRM practices have to be implemented in order to achieve organizational goals in a volatile competive environment. Human resources are highly valued organizational assets; hence the need to adopt HRM practices in order to remain competitive. Boyatzis (1982) defines competence as an individual's underlying characteristics which changes in certain situations. Competence is described as a skill, trait or a body of knowledge processed by an individual in line of duty. Rychen and Salganik, (2002) concurs that competence is the skill or aptitude to perform a complicated task within the set deadlines. Competence may be conceptualized as those individual dispositions such as goals, intentions and personal attributes attached to a particular position which result to improved performance.

Muindi (2015) observes that individuals' performance may be measured through observation as they perform complex and demanding tasks (Oates, 2001). On the basis of observations, a conclusion may be drawn that one is competent. An individual requires some core competences to enhance job performance. Regardless of size of organization (either large or small) there is need to consider some core competences expected from employees. Competences can be categorized into job or task-based competency and personal based competency (Woodruffe, 1992). Spencer and Spencer (1993) list three competency characteristics possessed by individuals, which include drives, behaviours, self-concept, knowledge and skills. Drives are the psychological features that drives one to act. Spencer (1993) further describes traits as physical characteristics and reactions to different situations, while the self-concept is a person's attitudes, ethics or self-perception. Knowledge refers to how much one is informed in relation to the assigned job. According to Spencer (1993), a skill is an ability to perform certain responsibilities. The unseen competences in this case are drives, behaviours and self-concepts, while the visible ones are knowledge and skills. The visible competencies are acquired through training and development as opposed to invisible which is innate.

\section{Literature Review}

Organizations are likely to achieve employee competency through adoption of the best training programs, upon employment of best HRM practices. June and Rosli (2011) observes that human capital is an important asset to a firm. They further assert that employee competency determines its success. The study established a linkage between role ambiguity, competency and job performance in Malaysia. For an organization to achieve its objectives there is need to train and retain competent employees. Azmi (2010) empirically showed that competency-based performance management, organizational development and career growth were widely practiced.

Such human resource practices enhance employee competence thus leading to performance. A study by Yazdanfar et al (2014) revealed a strong linkage between competence development programs and the organization's HRM practices. HRM practices such as training and development may therefore, enhance employee competencies thus improving employee performance. Muindi and K'Obonyo, (2015) in a critical literature on quality of work life, personality, job satisfaction, competence, and job performance observe that Employees' performance is the product of their competence. 


\section{Research Methodology}

Descriptive cross-sectional survey design was used in conducting the study. population of the study was the National Police Service. The National Police Service has an establishment of 105,200 officers distributed in all the 47 counties of Kenya. The unit of analysis was the national police officers. The sample size for the study was obtained through a formula by Muchhal (2014) as follows: $n=\left(z^{2} p q\right) / d^{2} \cdot n=$ the desired sample size (if the target population is greater than 10,000$) \mathrm{z}=$ the degree of confidence, which in this case was $95 \%$ confidence interval $\mathrm{p}$ $=$ the proportion in the target population estimated to have characteristics being measured, 0.5 was adopted. $q=$ $1-\mathrm{p}$ (this stands for the population not having the characteristics $0.5, \mathrm{~d}=$ the level of statistical significance (the degree of accuracy required in this case is $5 \%$.

$\mathrm{n}=\left(1.96^{2 *} .5^{*} .5\right) / .05^{2}$

$\mathrm{n}=384$.

Moderating effect was tested using stepwise regression analysis. The first step was to test the influence of Human Resource Management Practices on employee performance. The second step was to test the influence of Human Resource Management Practices and employee competence on employee performance. The third step was to test the interaction term influence. Moderation takes effect if the interaction term is significant ( $p$-value $<0.05)$.

\section{Research Findings and Discussions}

The study sought to determine the effect of employee competence on the relationship between HRM Practices and employee performance through formulation of the following hypothesis;

$\mathrm{H}_{1}$ : The Relationship between Human Resource Management Practices and Employee Performance is significantly moderated by Employee Competence.

This was tested by computing composite indices for Human Resource Management Practices dimensions, employee competence dimensions and employee performance dimensions. Stepwise regression analysis was performed. The results are presented in Table1.

Table 1: Moderating Effect of Employee Competence on the Relationship between Human Resource Management Practices and Employee Performance

\begin{tabular}{|c|c|c|c|c|c|c|c|c|c|c|}
\hline \multicolumn{11}{|c|}{ Model Summary $^{d}$} \\
\hline \multirow[b]{2}{*}{ Model } & \multirow[b]{2}{*}{$\mathrm{R}$} & \multirow[b]{2}{*}{ R Square } & \multirow[b]{2}{*}{$\begin{array}{l}\text { Adjusted } \quad \mathrm{R} \\
\text { Square }\end{array}$} & \multirow[b]{2}{*}{$\begin{array}{l}\text { Std. Error of the } \\
\text { Estimate }\end{array}$} & \multicolumn{5}{|c|}{ Change Statistics } & \\
\hline & & & & & $\begin{array}{l}\mathrm{R} \text { Square } \\
\text { Change }\end{array}$ & $\begin{array}{l}\mathrm{F} \\
\text { Change }\end{array}$ & dfl & $\mathrm{df} 2$ & $\begin{array}{ll}\text { Sig. } & F \\
\text { Change }\end{array}$ & \\
\hline 1 & $.569^{\mathrm{a}}$ & .323 & .321 & .93402 & .323 & 122.255 & 1 & 256 & .000 & \\
\hline 2 & $.811^{\mathrm{b}}$ & .658 & .655 & .66541 & .335 & 249.405 & 1 & 255 & .000 & \\
\hline 3 & $.815^{\mathrm{c}}$ & .665 & .661 & .65993 & .007 & 167.900 & 1 & 254 & .023 & \\
\hline \multicolumn{11}{|c|}{ ANOVA $^{\text {a }}$} \\
\hline \multicolumn{2}{|l|}{ Model } & $\begin{array}{ll}\text { Sum } & \text { of } \\
\text { Squares }\end{array}$ & df & Mean Square & $\mathrm{F}$ & Sig. & & & & \\
\hline \multirow[t]{3}{*}{1} & Regression & 106.655 & 1 & 106.655 & 122.255 & $.000^{\mathrm{b}}$ & & & & \\
\hline & Residual & 223.334 & 256 & .872 & & & & & & \\
\hline & Total & 329.989 & 257 & & & & & & & \\
\hline \multirow[t]{3}{*}{2} & Regression & 217.083 & 2 & 108.542 & 245.144 & $.000^{\mathrm{c}}$ & & & & \\
\hline & Residual & 112.906 & 255 & .443 & & & & & & \\
\hline & Total & 329.989 & 257 & & & & & & & \\
\hline \multirow[t]{3}{*}{3} & Regression & 219.368 & 3 & 73.123 & 167.900 & $.000^{\mathrm{d}}$ & & & & \\
\hline & Residual & 110.620 & 254 & .436 & & & & & & \\
\hline & Total & 329.989 & 257 & & & & & & & \\
\hline \multicolumn{11}{|c|}{ Coefficients $^{\mathrm{a}}$} \\
\hline \multirow{2}{*}{\multicolumn{2}{|c|}{ Model }} & \multicolumn{2}{|c|}{ Unstandardized Coefficients } & $\begin{array}{l}\text { Standardized } \\
\text { Coefficients }\end{array}$ & & & \multicolumn{2}{|c|}{$95.0 \%$ Confidence Interval for B } & \multicolumn{2}{|c|}{ Collinearity Statistics } \\
\hline & & $\mathrm{B}$ & Std. Error & Beta & $\mathrm{t}$ & Sig. & Lower Bound & Upper Bound & Tolerance & VIF \\
\hline \multirow[t]{2}{*}{1} & (Constant) & 1.217 & .229 & & 5.322 & .000 & .767 & 1.668 & & \\
\hline & $\begin{array}{l}\text { Human Resource } \\
\text { Practices }\end{array}$ & .855 & .077 & .569 & 11.057 & .000 & .702 & 1.007 & 1.000 & 1.000 \\
\hline \multirow[t]{3}{*}{2} & (Constant) & .545 & .168 & & 3.236 & .001 & .213 & .877 & & \\
\hline & $\begin{array}{l}\text { Human Resource } \\
\text { Practices }\end{array}$ & .199 & .069 & .132 & 2.881 & .004 & .063 & .334 & 637 & 1.569 \\
\hline & $\begin{array}{l}\text { Employee } \\
\text { Competence }\end{array}$ & .748 & .047 & .725 & 15.793 & .000 & .655 & .842 & .637 & 1.569 \\
\hline \multicolumn{11}{|c|}{ Coefficients } \\
\hline \multirow{2}{*}{\multicolumn{2}{|c|}{ Model }} & \multicolumn{2}{|c|}{ Unstandardized Coefficients } & $\begin{array}{l}\text { Standardized } \\
\text { Coefficients }\end{array}$ & $\mathrm{t}$ & Sig. & \multicolumn{2}{|c|}{$95.0 \%$ Confidence Interval for B } & \multicolumn{2}{|c|}{ Collinearity Statistics } \\
\hline & & $\mathrm{B}$ & Std. Error & Beta & & & Lower Bound & Upper Bound & Tolerance & \\
\hline & & & & & & & & & & \\
\hline \multirow[t]{4}{*}{3} & (Constant) & -.538 & .502 & & -1.073 & .284 & -1.526 & .449 & & \\
\hline & $\begin{array}{l}\text { Human Resource } \\
\text { Practices }\end{array}$ & .642 & .205 & .427 & 3.128 & .002 & .238 & 1.046 & .071 & 14.119 \\
\hline & $\begin{array}{l}\text { Employee } \\
\text { Competence }\end{array}$ & 1.080 & .152 & 1.046 & 7.092 & .000 & .780 & 1.380 & .061 & 16.483 \\
\hline & Interaction Term & -.128 & .056 & -.558 & -2.291 & .023 & -.239 & -.018 & .022 & 44.941 \\
\hline a. Depe & ent Variable: employ & performance & & & & & & & & \\
\hline b. Predi & ors: (Constant), Hum & Resource Pract & & & & & & & & \\
\hline c. Predi & rrs: (Constant), Hum & Resource Pract & es, Employee Cor & petence & & & & & & \\
\hline d. Predi & ors: (Constant), Hum & Resource Pract & es, Employee Co & petence, Interaction & & & & & & \\
\hline
\end{tabular}

Source: Field Data, (2019)

In step one HRM practices accounts for 32.3 percent of the variation in the employee performance $\left(\mathrm{R}^{2}=\right.$ $0.323)$. The model was significant $(\mathrm{F}=122.225$, $\mathrm{P}-\mathrm{V}$ alue $=0.000<0.05)$. Beta coefficient of HRM practices was also individually significant $(\beta=0.855, \mathrm{t}=11.507$, $\mathrm{p}$-value $=0.00<0.05)$. $\mathrm{R}$ squared change of 0.323 was significant. 
Step one which states that the relationship between independent and dependent variable is significant was confirmed, thus move to step two of moderation effect.

In step two, the study introduced the moderator variable. Both moderator and independent variables were treated as independent variables and regressed against the dependent variable. The explanatory power $\left(\mathrm{R}^{2}\right)$ improved from 0.323 to 0.658 . This resulted in a significant $\mathrm{R}^{2}$ change of 0.335 . When moderator variable (employee competence) is introduced to the model, 65.8 percent of the variation in employee performance were explained by the changes in both HRM practices and employee competence. The model was significant $(\mathrm{F}=$ 245.144, P-Value $=0.000<0.05)$. Beta coefficient for both HRM practices $(\beta=0.199, \mathrm{t}=2.881, \mathrm{p}$-value $=$ $0.04<0.05)$ and employee competence $(\beta=0.748, \mathrm{t}=15.793$, $\mathrm{p}$-value $=0.00<0.05)$ were also individually significant. Step two which states that when moderator variable is introduced in the model, the relationship between the independent variable, moderator variable and dependent variable is significant was confirmed, thus move to step three.

In step three, the interaction term was introduced in the model. Moderation takes place if the interaction term is significant. The explanatory power $\left(\mathrm{R}^{2}\right)$ improved significantly from 0.659 to 0.665 . Further coefficient of determination showed that 66.5 percent of the variation in employee performance was accounted for by the changes in HRM practices, employee competence and interaction term. The result shows significant $\mathrm{R}^{2}$ change of 0.07 . The model was overally significant $(\mathrm{F}=167.900, \mathrm{P}-$ Value $=0.000<0.05)$. Beta coefficient for interaction term $(\beta$ $=-0.128, \mathrm{t}=-2.291, \mathrm{p}$-value $=0.023<0.05)$ was significant, thus the results in step three was significant. Hypothesis that the Relationship between Human Resource Management Practices and Employee Performance is significantly moderated by Employee Competence was supported.

\section{Conclusion}

The study established that employee competence moderates the relationship between HRM Practices and employee performance. The study revealed that revealed that technical/professional skills, general skill/attributes, experience moderated the relationship between HRM Practices and employee performance while knowledge/skills, did not moderate the relationship between HRM Practices and employee performance. The results concur with Spencer and Spencer (1993), who argued that competencies are the capacities that exist within a person and which envisage superior performance, needed to cope with current and future requirements to remain competitive. The findings are supported by Harter et al (2002) who posited that when employees have clear idea in terms of job expectation and the strategic goals of the firm, task and jobs are designed in line with these set targets, then employees' commitment to their jobs will improve. The study makes a contribution to theories by agreeing with human capital theory that human capital is highly valued in organizations.

\section{Recommendations}

The results of this study have established that employee competence moderates the relationship between human resource management practices and employee performance at the National Police Service. Similar study could also be done using the private security sector in Kenya especially this time when the private security guards are being empowered by issuing them with guns

\section{Limitation of the Study}

During the research process the researcher encountered some limitations though they did not interfere with the current outcome. The scope of the study was limited to the Kenyan security sector which means that the findings are only limited in that they may not be applicable to other international contexts. Another limitation was that though the respondents were expected to be objective in their responses, different context may not allow this. This might have had an effect in the way they responded to Questions though it also did not affect the affect the outcome of the study.

\section{References}

Abdul G. A. (2014) Impact Of Professional Training On Employees' Performance: A Case Study of Pakistani Banking Sector A Case Study Of Hdfc Bank, European Journal of Accounting Auditing and Finance Research 2(1), 62-68.

Azmi, I. A. G. (2010). Competency-based human resource practices in Malaysian public sector organizations. African Journal of Business Management, 4(2), 235-241.

Connolly, J. J., Viswesvaran, C. (2000). The role of affectivity in job satisfaction: A meta-analysis. Personality and Individual Differences, 29(2), 265-281.

Indermun, V. (2014). Importance of Human Resource Management Practices and the Impact Companies Face in Relation To Human Resource Management ( Hrm ) Practices, 2(11), 125-135.

June, S., \& Rosli, M. (2011). The relationship between role ambiguity, competency and person-job fit with the job performance of employees in the service sector SMEs in Malaysia. Business Management Dynamics, 1(2), 
79-98.

Kahn, W. A. (1990). The psychological conditions of personal engagement and disengagement at work. Academy of Management Journal, 33, 692-7

Muchhal, D. S. (2014). HR Practices and Job Performance, Journal of Humanities and Social Science (2014) 19(4) 55-61 19(4), 55-61.

Muindi F.K (2015) Quality of Work Life, Personality, Job Satisfaction, Competence and Job Performance: A Critical Review of Literature European Scientific Journal September 2015 edition vol.11, No.26 ISSN: 1857 - 7881 (Print) e - ISSN 1857- 7431

Oates, T. (2001). Key Skills/Key Competencies - avoiding the pitfalls of current initiatives. In Additional DeSeCo Expert Papers, briefing materials prepared for DeSeCo's 2nd International Symposium. Neuchâtel, Switzerland: Swiss Federal Statistical Office.

Rychen, D. S. \& Salganik, L. H. (Eds.). (2001). Defining and Selecting Key Competencies. Göttingen, Germany: Spencer, L.M. \& Spencer, S.M. (1993). Competence at Work: Models for Superior Performance, John Wiley \& Sons, Inc., New York, NY.

Woodruffe, C. (1992). What is meant by a competency? In R. Boam \& P. Sparrow (Eds.), Designing and Achieving Competency: A Competency-Based Approach to Developing People and Organisations (pp. 16-30). Berkshire, England: McGraw-Hill 